\title{
WATER-SOLUBLE CHEMISTRY AND WEATHERING CHARACTERISTICS OF SOME TILLS IN WESTERN DRONNING MAUD LAND, ANTARCTICA
}

\author{
PETRI LINTINEN and JARI NENONEN
}

LINTINEN, PETRI and \& NENONEN, JARI 1997. Water-soluble chemistry and weathering characteristics of some tills in Western Dronning Maud Land, Antarctica. Bull. Geol. Soc. Finland 69, Part 1, 57-71.

The water-soluble chemistry and weathering characteristics of tills were studied on three nunataks with differing bedrock characteristics in the Vestfjella and Heimefrontfjella areas of the Western Dronning Maud Land, Antarctica. The chemical analyses were performed using ion chromatography and ICP-AES. The relative weathering characteristics of the till surface boulders was assessed in study locations.

No colour differences were observed in test pits dug in Basen and Utpostane nunataks at Vestfjella, whereas the till in Mygehenget nunatak at Heimefrontfjella has a pronounced soil profile in which the surface part has a banded rusty brown and light-coloured accumulations. The highest concentrations of readily soluble ions were recorded in the Mygehenget samples characterised by high $\mathrm{SO}_{4}{ }^{2-}(5800-39000 \mathrm{ppm})$ and $\mathrm{Mg}^{2+}$ concentrations (540$6000 \mathrm{ppm})$, while the Basen samples had the highest concentrations of $\mathrm{Fe}^{2+}$ (23-390 ppm), $\mathrm{Al}^{3+}(60-1000 \mathrm{ppm})$ and $\mathrm{Si}^{4+}(23-1700 \mathrm{ppm})$ and the Utpostane samples the lowest ones. The $\mathrm{SO}_{4}{ }^{2-} / \mathrm{Na}^{+}, \mathrm{Na}^{+} / \mathrm{CI}-$ and $\mathrm{Mg}^{2+} / \mathrm{Na}^{+}$ratios for the samples differ markedly from those typically encountered in sea water. The presence of the highest concentrations of many of the analysed ions in the Mygehenget soil samples is in line with the advanced weathering of the surface boulders. The high $\mathrm{Fe}^{2+}, \mathrm{Si}^{4+}$ and $\mathrm{Al}^{3+}$ concentrations in the Basen samples may be attributable to the weathering of olivine alteration products.

Keywords: soils, till, chemical composition, ions, $\mathrm{pH}$, nunataks, weathering, Queen Maud Land, Antarctica

Petri Lintinen, Finnish Institute of Marine Research, P.O. Box 33, SF-00931 Helsinki, Finland.

Jari Nenonen, Geological Survey of Finland, P.O. Box 77, SF-96101 Rovaniemi, Finland. 


\section{INTRODUCTION}

The soils of Antarctica are unique in many respects, reflecting the extreme conditions prevailing in the region. The ground is frozen for most of the year and most areas are as arid as the Sahara or Gobi Deserts (Campbell \& Claridge 1987). Conditions favourable for chemical weathering are restricted to the short summer period when temperature allow free water to exist in the active layer above the permafrost table. Although the summer in Antarctica is short, many dry areas have been ice-free for an extremely long time. Till surfaces dating back several hundred thousand years, or even some million years, have been reported in the Dry Valley areas of the Transantarctic mountains, for example (Brook et al. 1993, Marchant et al. 1994). One feature typical of superficial deposits in Antarctica are salt accumulations (Dort \& Dort 1972). The salts in the coastal areas originate from marine aerosols, whereas the upper atmosphere may be the main source in the inland areas. Small quantities of salt may originate from chemically altered fine fractions of till or the regolith cover. One common feature of the superficial deposits is that ion concentrations tend to increase with the exposure age of the soil (Campbell \& Claridge 1987).

Although chemical weathering is limited, conditions are favourable for physical weathering (Kelly \& Zumberge 1961). Daily differences between maximum and minimum temperatures in summer may be as much as $30^{\circ} \mathrm{C}$, and meltwater percolating through the superficial cover may freeze effectively during the night, thus giving rise to intense frost weathering. This serves to break up the bedrock surface, raising the specific surface of the fine matter in the surface parts of the weathered sections and thereby increasing the surface area susceptible to chemical changes.

This report is concerned with the water-soluble chemical characteristics of some soils observed in the surficial part of the till deposited in various nunatak areas in Western Dronning Maud Land representing different bedrock types. The age relations between the soils in these areas are discussed on the basis of dating results and the weathering characteristics of the tills. The results of the chemical analyses of soil samples are compared with the mineralogy and lithology of the tills and with the sea water chemistry in order to discuss possible sources of water-soluble ions.

\section{THE AREA STUDIED}

The Vestfjella nunatak range $\left(73-74^{\circ} \mathrm{S}, 13-\right.$ $\left.16^{\circ} \mathrm{W}\right)$ at Maudheimvidda in Western Dronning Maud Land, Antarctica, is $130 \mathrm{~km}$ in length and trends parallel to the coastline (Fig. 1). It is situated approximately $120 \mathrm{~km}$ from the coast, and its highest summits reach approximately $1100 \mathrm{~m}$ a.s.l. Its northern and southern nunataks are located only a few kilometres away from the present ice sheet grounding-line. The difference in altitude between the nunatak peaks and the surface of the ice sheet is usually between ten and a few hundred metres, the maximum being $700 \mathrm{~m}$. Vestfjella is mainly composed of Jurassic basaltic lava extrusions (Furnes et al. 1987). The Fossilryggen nunataks in the northern part of Vestfjella contain Permian sedimentary rocks (Hjelle \& Winsnes 1972), while the basalts are perforated by a gabbro intrusion on Utpostane in the southern part (Räisänen 1996).

About $150 \mathrm{~km}$ inland from Vestfjella there is another nunatak range, Heimefrontfjella (74$\left.75^{\circ} \mathrm{S}, 10-13^{\circ} \mathrm{W}\right)$, some $150 \mathrm{~km}$ long and with its highest summits rising to $2600-2700 \mathrm{~m}$ a.s.l. (Fig. 1). The ice sheet reaches the level of the nunatak peaks on the inland side of the mountain chain but lies several hundred metres below them on the coastal side. Heimefrontfjella constitutes an effective dam to ice flow which is chanelled through several outlet glaciers. The bedrock of Heimefrontfjella is composed of Precambrian gneisses and schists (Jacobs 1991).

Evidence derived from glacial striae, the relatively unweathered nature of till surface boulders and radiocarbon dates obtained for nesting sites (stomach oil deposits, Fig. 2) of the snow petrel, Pagodroma nivea, suggest that the entire Vestfjella area and the lowermost parts of Heime- 


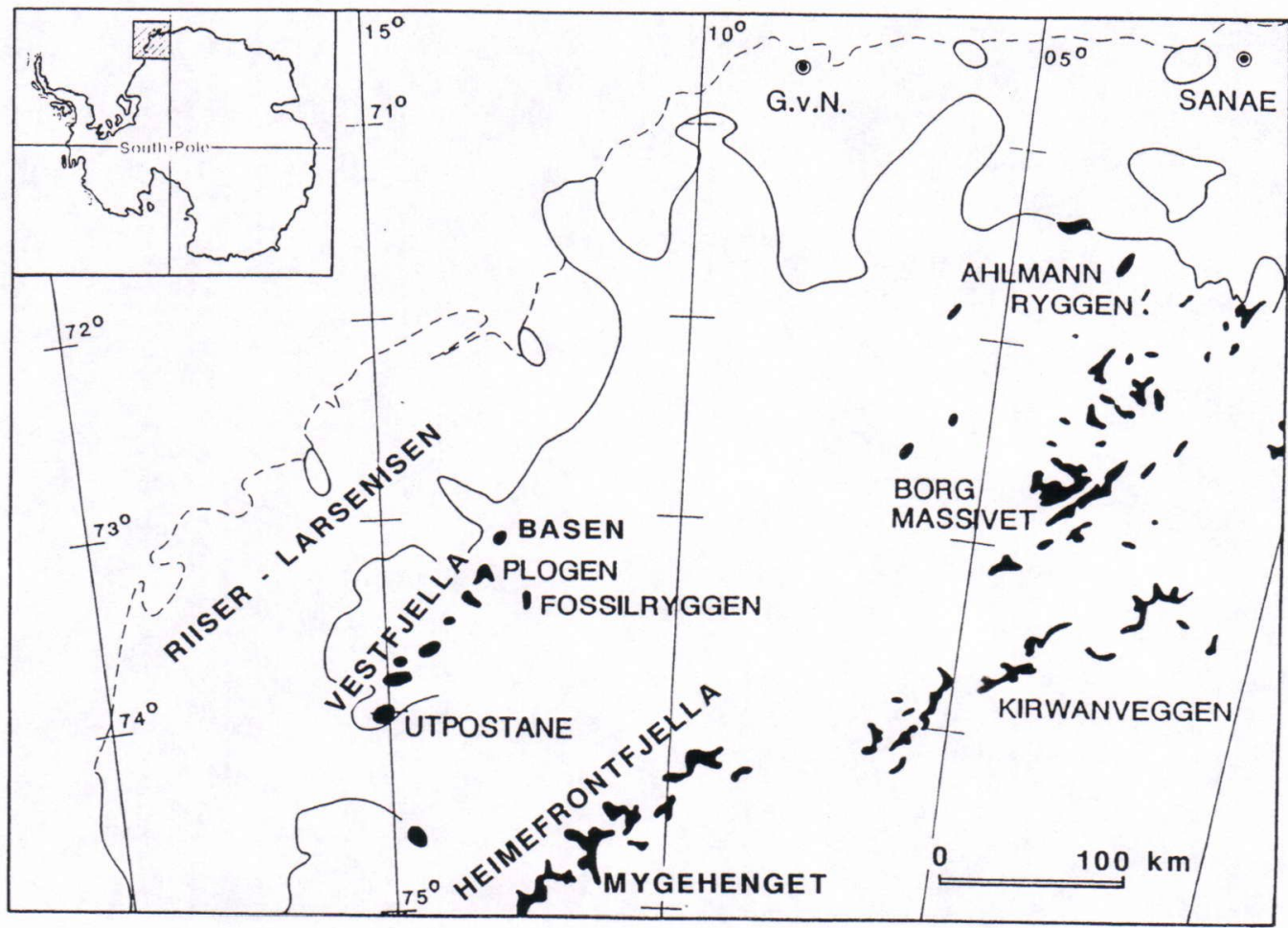

Fig. 1. Map of Western Dronning Maud Land with the main place names referred to in the text. Note that the nunataks are not drawn to scale.

frontfjella were covered by the ice sheet as it progressed towards the shelf edge approximately 20 ka ago (Lintinen \& Nenonen 1995, 1997).

The mean annual temperature at Basen is $-16^{\circ} \mathrm{C}$ (Taalas et al. 1991), and measurements at a depth of $10 \mathrm{~m}$ in firn suggest an annual mean temperature of $-24^{\circ} \mathrm{C}$ to $-34^{\circ} \mathrm{C}$ for Heimefrontfjella (Isakson 1992). The annual snowfall is approximately $30 \mathrm{~mm}$ in the area between Vestfjella and Heimefrontfjella, but approximately $15 \mathrm{~mm}$ east of the latter (Holmlund et al. 1989, Holmlund \& Näslund 1994).

\section{METHODS}

The weathering characteristics of stones and boulders at the till surfaces were examined visually, and the relative weathering indices (1-6) of Campbell and Claridge (1987) were used to classify the degree of weathering. The physical properties of the till and the soil were examined visually in pits dug with a spade. Grain-size distribution was examined by the conventional combination of wet-sieving and the hydrometer method. The till pebble fabric was determined by measuring the directions of dip of 50 elongated pebbles.

The water-soluble chemical composition of the till samples was determined by extraction with distilled water. The samples were sieved using a $2 \mathrm{~mm}$ screen and the fraction passing through the screen was extracted in distilled 


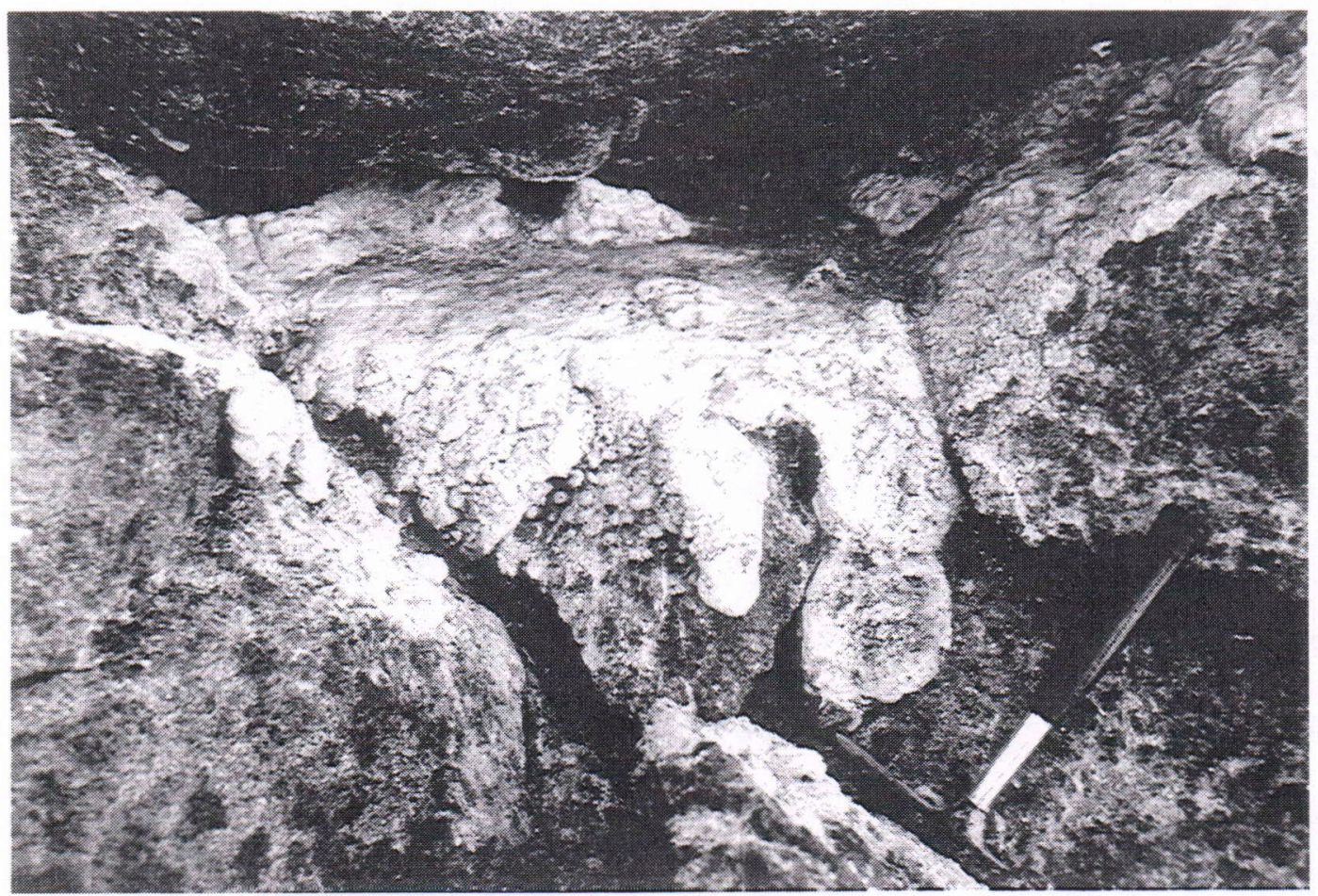

Fig. 2. A nesting site of the snow petrel, Pagodroma nivea, at Utpostane, dated to around 8000 B.P.

water in a shaker for several hours. The samples were then centrifuged and filtered, and the $\mathrm{pH}$ of the resulting clear solution was determined with a potentiometer (Radiometer 85 ion analyzer). CI-, $\mathrm{NO}_{3}{ }^{-}, \mathrm{SO}_{4}{ }^{2-}$ concentrations were determined by ion chromatography (Deionex 2000i) and $\mathrm{Al}^{3+}, \mathrm{Ca}^{2+}, \mathrm{Fe}^{2+}, \mathrm{K}^{+}, \mathrm{Mg}^{2+}, \mathrm{Mn}^{2+}$, $\mathrm{Cu}^{+}, \mathrm{Na}^{+}, \mathrm{Ni}^{2+}, \mathrm{Ti}^{4+}, \mathrm{V}^{4+}$ and $\mathrm{Zn}^{2+}$ concentrations by ICP-AES (Jarell ASH) at the chemical laboratory of the Geological Survey of Finland (GSF). Only those ion concentrations which clearly exceeded the limit of detection will be discussed here.

The mineralogical composition of the till clay fraction $(<0.002 \mathrm{~mm})$ was examined by the $\mathrm{X}$-ray diffraction method. The clay fraction was separated in tubes after settling time based on Stoke's Law and analysed as oriented aggregates using $\mathrm{Ni}$-filtered $\mathrm{Cu}$ radiation at the mineralogical laboratory of the GSF. The samples were analysed after $\mathrm{Mg}^{2+}$ and $\mathrm{K}^{+}$saturation at room temperature and heated at $200^{\circ} \mathrm{C}$ and $550^{\circ} \mathrm{C}$. The occurrence of smectite was tested by ethyleneglycol treatment. The mineralogical determinations were based on Wilson (1987).

\section{RESULTS}

\section{Basen}

The main superficial cover on the Vestfjella nunataks is a frost-weathered regolith which varies from block fields to a more fine-grained material (Lintinen 1996). Of the Vestfjella nunataks, a till cover is most common on Basen, most notably on its top plateau, while another extensive tillcovered area is found on the plain on the southeast slope (Jonsson 1988). The cobble fraction of the till originates mainly from the local bed- 


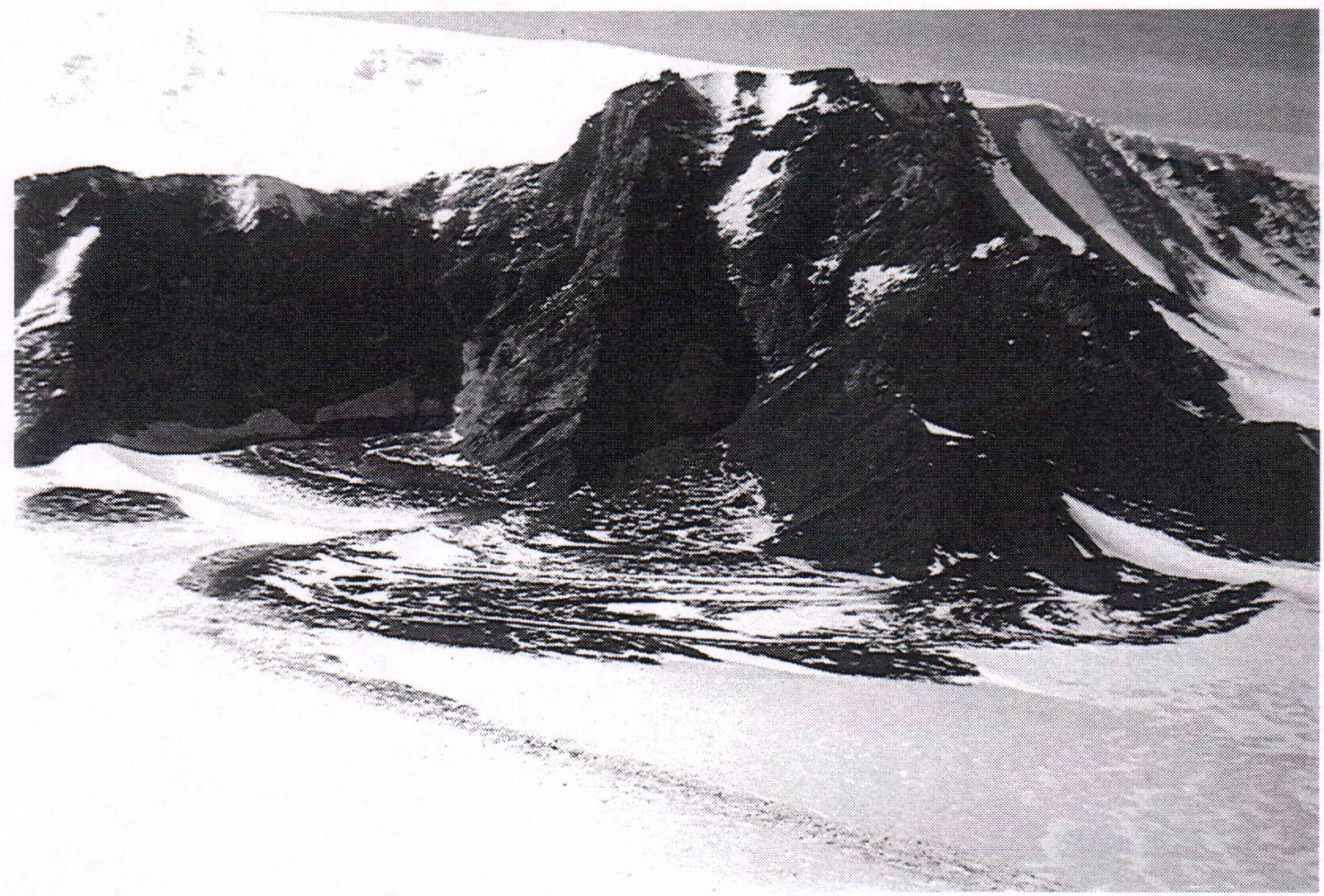

Fig. 3. Oblique aerial photograph of the Heimefrontfjella nunataks in the Scharffenbergbotnen area. The difference in altitude between the nunatak summits and the ice sheet surface in the foreground is some $1000 \mathrm{~m}$.

rock, with occasional occurrences of long-distance gneiss and schist erratics. Bulk till samples from Basen contained 5-17\% clay fraction. The most abundant minerals in clay aggregates were illite, kaolinite and vermiculite, with a small amount of smectite (Lintinen 1996), the latter being derived from the weathering products of local basalts and the kaolinite and illite from Permian shales. X-ray diffraction analyses indicated that the light-coloured accumulates detected beneath the surface boulders of the Basen till were either calcite or thenardite (Lintinen 1991).

The till at Vestfjella is structureless and may be classified as basal or lodgement till deposited at the base of an actively flowing glacier (Lintinen 1996). It shows no signs of soil formation in terms of colour differences in the top parts of the sections. The only indication of weather- ing is oxidation and slight polishing of the surface stones. The till on the Vestfjella nunataks represents class 2 in the weathering classification on a scale of 1 to 6 proposed by Campbell and Claridge (1987).

The chemical composition of the till samples obtained from the pit dug in the till cover of the plateau on the eastern slope of the Basen nunatak is indicated in Fig. 5. The highest water-soluble concentration in the surface part of the profile was recorded for sulphate (1300 ppm), and the values for $\mathrm{Si}^{4+}$ (1530-1760 ppm) and $\mathrm{Al}^{3+}(900-$ $1060 \mathrm{ppm}$ ) at depth $20-30 \mathrm{~cm}$ were also extremely high. The vertical distributions of these concentrations indicate that $\mathrm{SO}_{4}{ }^{2-}$ and $\mathrm{Ca}^{2+}$ vary in parallel and likewise $\mathrm{NO}_{3}-, \mathrm{CI}-$ and $\mathrm{Na}^{+}$, while a third group comprises $\mathrm{Al}^{3+}, \mathrm{Fe}^{2+}$ and $\mathrm{Si}^{4+}$, with almost identical vertical variation in their concentrations. The $\mathrm{Mg}^{2+}$ content is highest in the 
surface part though it also shows the extensive maximum at depths of $20-30 \mathrm{~cm}$ typical of the $\mathrm{Al}^{3+}, \mathrm{Fe}^{2+}$ and $\mathrm{Si}^{4+}$ concentrations. The average $\mathrm{pH}$ of the Basen samples was 8.9 , the $\mathrm{Na}^{+} / \mathrm{CI}$ ratio 1.34 , the $\mathrm{SO}_{4}{ }^{2-} / \mathrm{Na}^{+}$ratio 0.80 and the $\mathrm{Mg}^{2+} / \mathrm{Na}^{+}$ratio 0.36 . The corresponding ion ratios in the sea water are $0.55,0.25$ and 0.13 (CRC Handbook of Chemistry and Physics, 1989).

\section{Utpostane}

Till occurs in the Utpostane nunataks only in the wind scoop of the westernmost, unnamed nunatak. The surface boulders are composed of local gabbro and basalt, with some rounded gneisses cobbles transported from further inland. Fine-grained basaltic rocks have some polished surfaces. The till in the pit dug at Utpostane possessed a weak banded structure and no singn of coloror differences related to pedegenesis were observed. The Utpostane till is sandy and contains 2-4 \% clay fraction in bulk samples. The pebble fabric show broad maximum suggestive of deposition by ice flowing from the inland towards the coast. The Utpostane till and soil belongs in class 2 in the classification of Campbell and Claridge (1987).

$\mathrm{X}$-ray traces of the clay fraction aggregates gave prominent $7.1 \AA$ and $14 \AA$ reflections, with a markedly weaker $10 \AA$ reflection. The $14 \AA$ reflection strengthened considerably when the sample was heated at $550^{\circ} \mathrm{C}$, and the $7.1 \AA$ one became weaker. The primary mineral in the samples is chlorite, accompanied by very much smaller quantities of illite. No differences were observed in the behaviour of mica and chlorite in the samples representing various depths after $\mathrm{K}^{+}$saturation and heat treatment.

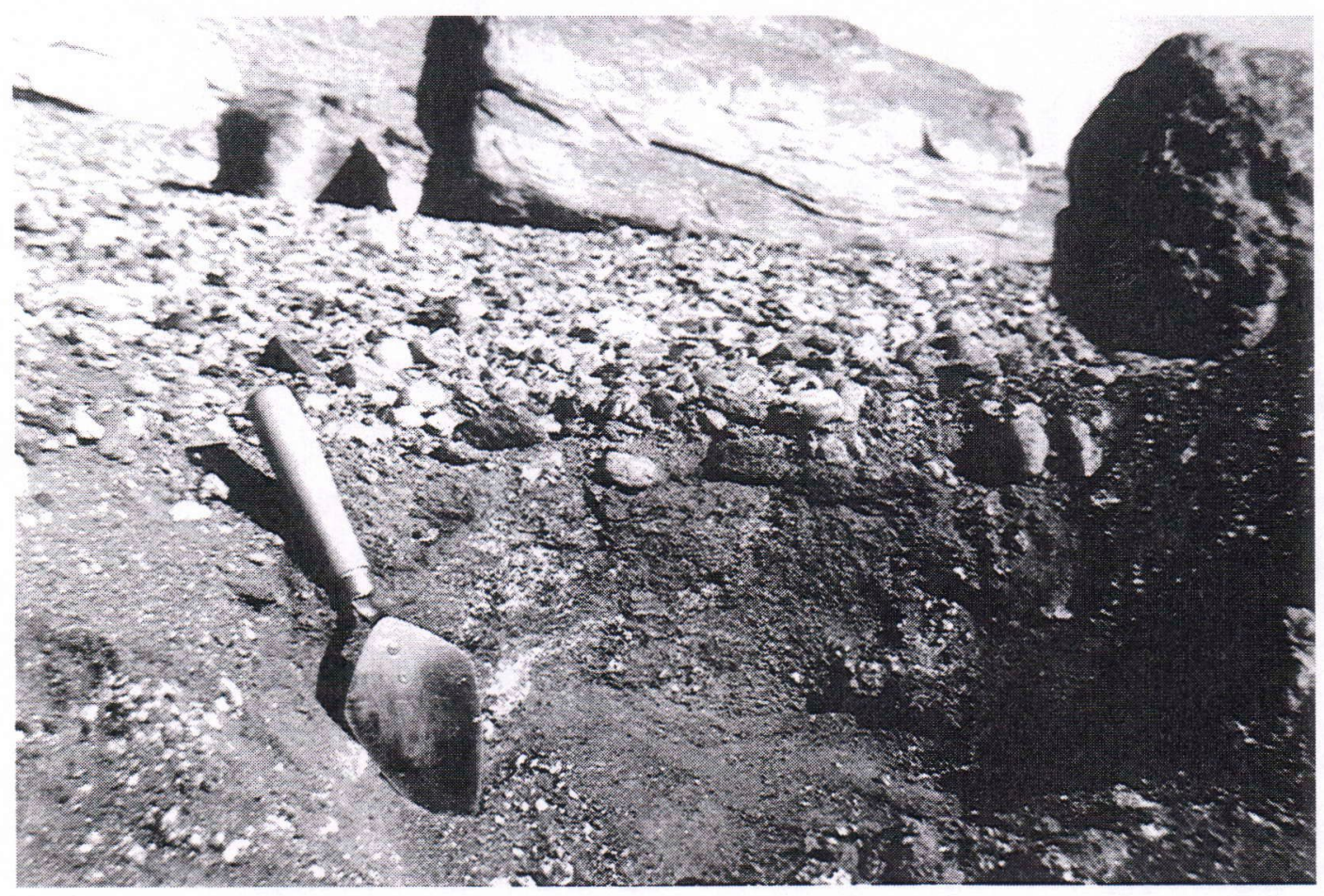

Fig. 4. Till from the Mygehenget nunatak at Heimefrontfjella, representing class 4 in the weathering classification of Campbell and Claridge (1987). 


\section{BASEN}
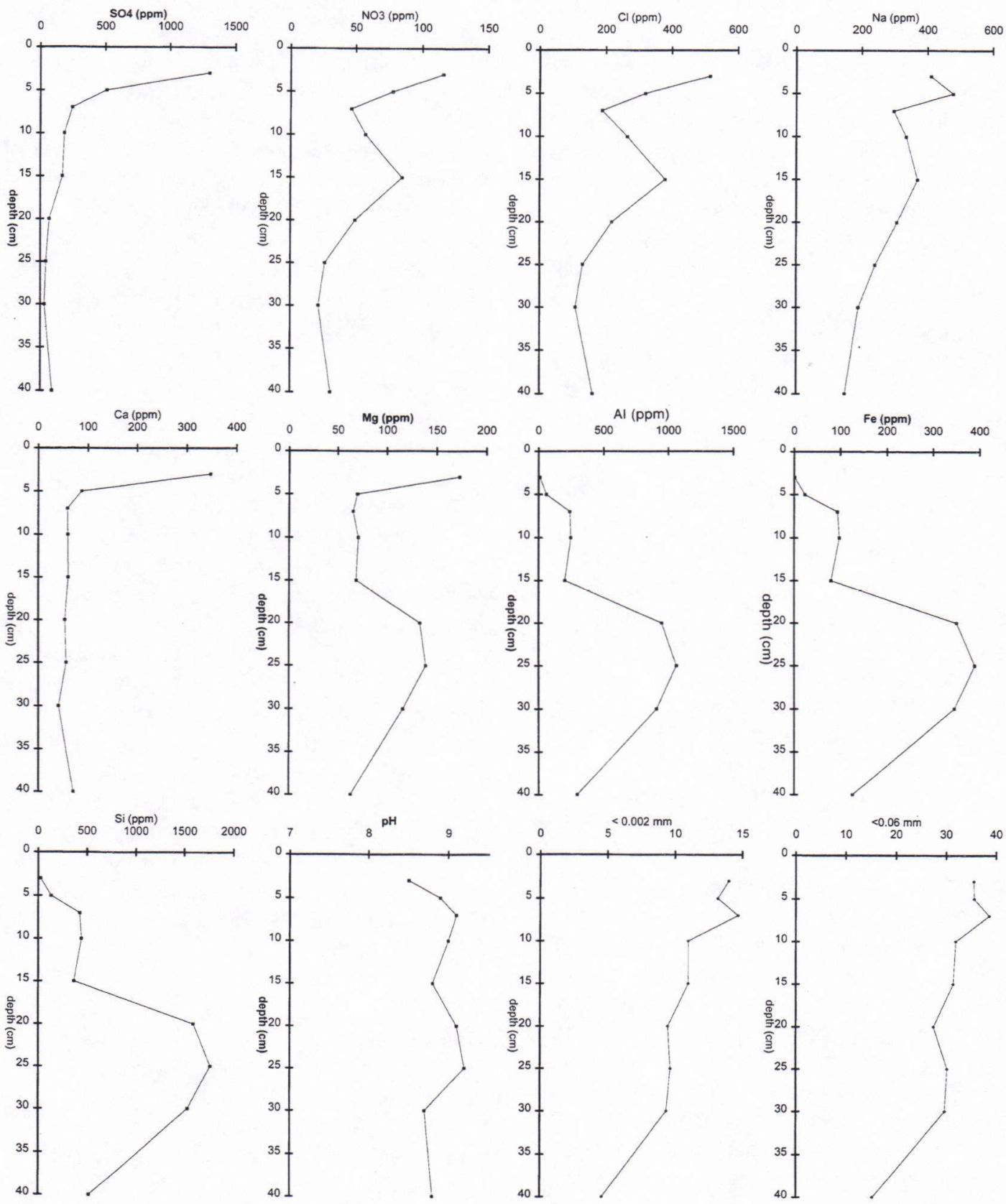

Fig. 5. Water-soluble chemical composition and $\mathrm{pH}$ of soil samples from the Basen nunatak in the northern part of Vestfjella, and content of the $<0.002$ and $<0.06 \mathrm{~mm}$ fractions. 
The water-soluble chemical composition and $\mathrm{pH}$ of the soil samples obtained from Utpostane, and the amounts of the clay and fine fractions are indicated in Fig. 6. The concentrations of all water-soluble ions are markedly below those recorded for the Basen samples, the highest concentrations being obtained for sulphate (50-100 ppm). Although no appreciable vertical variation could be observed in either the ion concentrations or the $\mathrm{pH}$ values, the ions can be divided into groups which show weak internal correlations. The $\mathrm{NO}_{3}-, \mathrm{Cl}-, \mathrm{Na}^{+}$concentrations parallel each other, as do $\mathrm{Ca}^{2+}$ and $\mathrm{Mg}^{2+}$ and likewise $\mathrm{Mn}^{2+}$ and $\mathrm{Si}^{4+}$. The average $\mathrm{pH}$ of the water extractions from the Utpostane soil samples was 4.7 , the $\mathrm{Na}^{+} / \mathrm{CI}$ - ratio was 1.30 , the $\mathrm{SO}_{4}{ }^{2-} / \mathrm{Na}^{+}$ ratio 5.45 and the $\mathrm{Mg}^{2+} / \mathrm{Na}^{+}$ratio 0.50 .

\section{Heimefrontfjella}

The main surficial cover of the Heimefrontfjella nunataks is a frost weathered regolith. The slopes are usually too steep for till preservation in the course of slope processes. Relatively unweathered erratics, as mentioned earlier by Pazelt (1988), can be found up to 100-200 above the present ice surface at Scharffenbergbotnen (Fig. 3). No colour differences were noted in sections dug into the regolith cover in the area of unweathered erratics, indicating only slight soil weathering. The surficial cover may represent class 2 in the weathering classification of Campbell and Claridge (1987).

Distinctively weathered till and regolith surfaces were found on three nunataks located some $10 \mathrm{~km}$ apart in the area of the Kibergdalen outlet glacier (Kibergbreen), and the largest till-covered area (300 x $200 \mathrm{~m}$ ) was found on the eastern side of the Mygehenget nunatak, slightly above the altitude of the present ice sheet surface. The till surface possessed a concentration of rounded quartzite and gneiss cobbles (Fig. 4). The schist clasts found beneath the stone pavement suggest that the most resistant local bedrock types were enriched in the surficial stones. The soil at the top of the section examined had a variable light brown to rusty yellow colour through oxidization, while another common feature was the presence of salt encrustations. The Mygehenget till and soil may fall into class 4 in the weathering classification of Campbell and Claridge (1987).

The clast fabric in the Mygehenget till was extremely well developed, with a strong mode of clasts dipping in the direction of 240 (Lintinen \& Nenonen 1995, 1997). The till was sandy and contained pebbles, cobbles and boulders. The clay fraction and fines contents of the bulk samples decreased in the deeper parts of the profile. The till was slightly stratified and may be classified as a basal till.

$\mathrm{X}$-ray analyses of the clay fraction of the Mygehenget till samples gave prominent $10 \AA$, $5.0 \AA$ and $3.3 \AA$ reflections, suggesting that the primary mineral is unweathered mica.

The water-soluble chemical composition of the Mygehenget soil profile is presented in Fig. 7., together with $\mathrm{pH}$ values and clay and fine fraction content. The chemical composition is characterised by high $\mathrm{SO}_{4}^{2-}, \mathrm{Mg}^{2+}$ and $\mathrm{Ca}^{2+}$ and as well high $\mathrm{Al}^{3+}$ and $\mathrm{Ni}^{2+}$ concentrations. The average sulphate content is $16590 \mathrm{ppm}$, and a figure of $39000 \mathrm{ppm}$ is reached in the surface part. The $\mathrm{Ca}^{2+}$ content is $830-1680 \mathrm{ppm}$ and the average $\mathrm{Mg}^{2+}$ content is $4000 \mathrm{ppm}$. The vertical variations in ion content indicate that $\mathrm{Mg}^{2+}$, $\mathrm{Mn}^{2+}$ and $\mathrm{Ni}^{2+}$ vary largely in parallel, likewise $\mathrm{NO}_{3}^{-}, \mathrm{CI}-$ and $\mathrm{Na}^{+}$. The average $\mathrm{pH}$ of the Mygehenget samples was 4.8 , the $\mathrm{Na}^{+} / \mathrm{CI}$ - ratio 0.62 , the $\mathrm{SO}_{4}{ }^{2-} / \mathrm{Na}^{+}$ratio 5.45 and the $\mathrm{Mg}^{2+} / \mathrm{Na}^{+}$ ratio 0.50 .

\section{DISCUSSION}

Soil investigations generally point to the role of the atmosphere as the main source of the salts observed in the ice-free areas of Antarctica (Campbell \& Claridge 1987, Gore et al. 1996). Atmospheric aerosols and the resulting ions which enter the ground through precipitation are derived either from aerosols carried by air masses from the surrounding oceans or from 

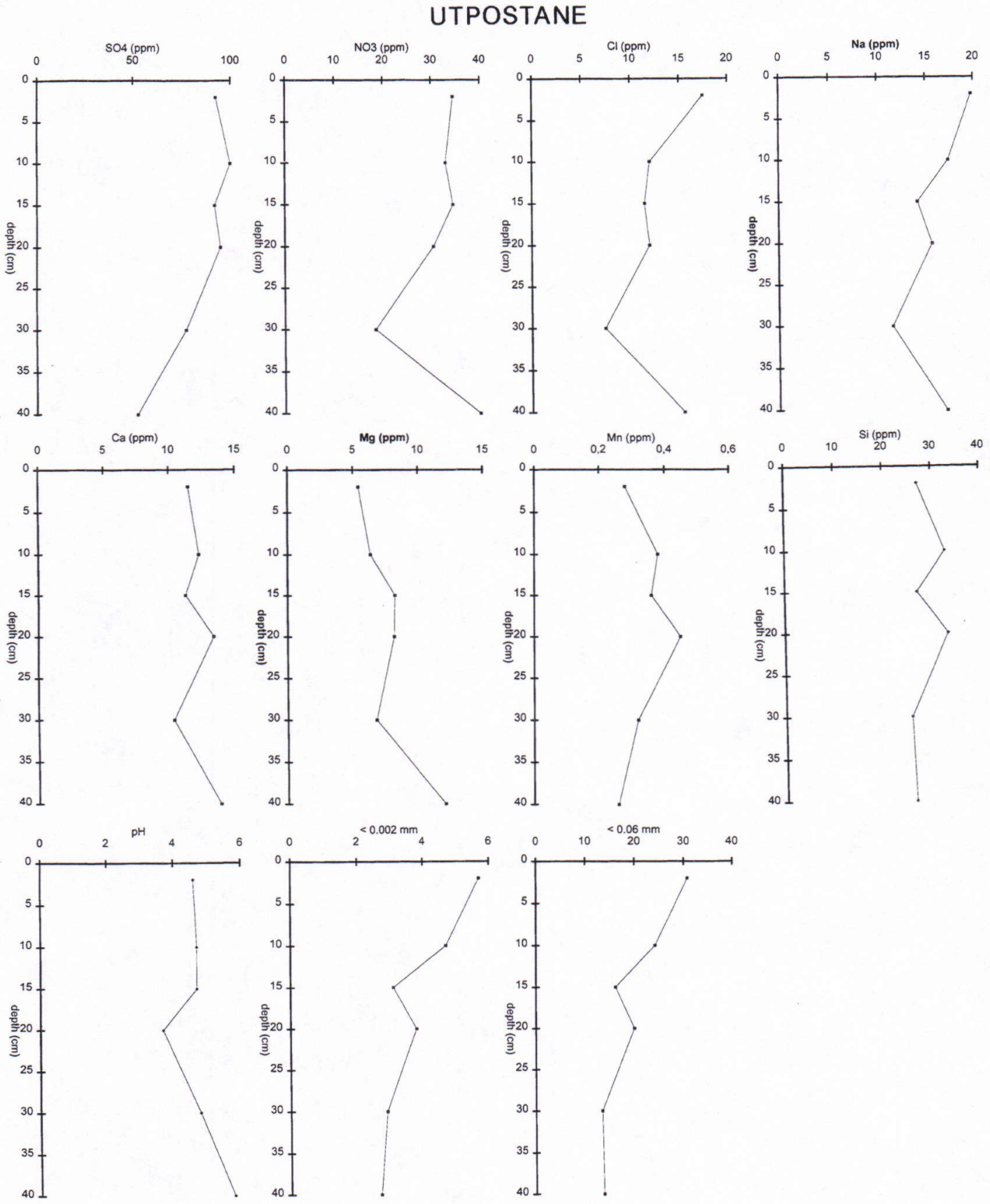

Fig. 6. Water-soluble chemical composition and $\mathrm{pH}$ of soil samples from a nunatak in the Utpostane range in the southern part of Vestfjella, and content of the $<0.002$ and 0.06 fractions. 
MYGEHENGET
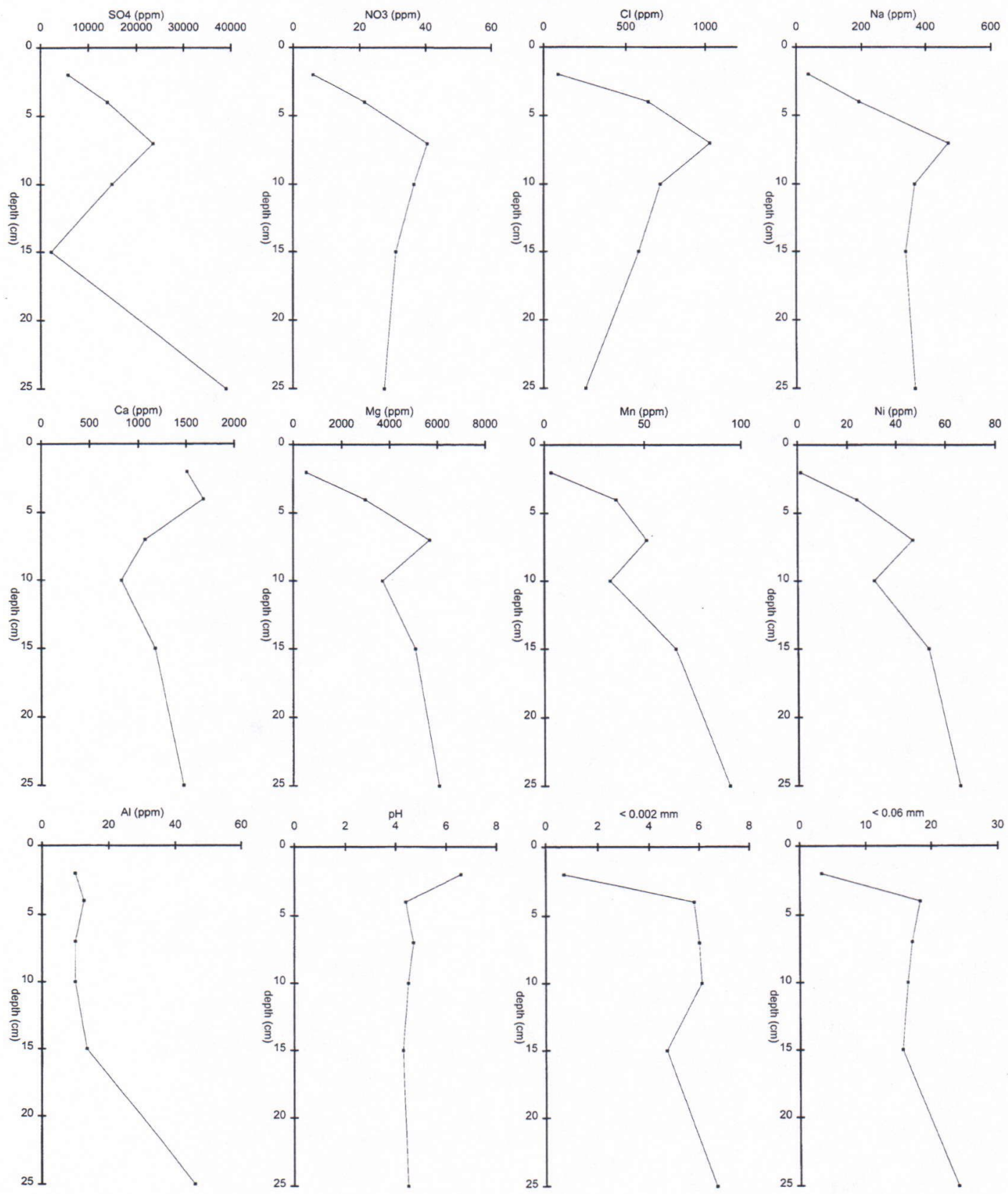

Fig. 7. Water-soluble chemical composition and pH of soil samples from the Mygehenget nunatak at Heimefrontfjella, and content of the $<0.002$ and $<0.06 \mathrm{~mm}$ fractions. 
chemical processes taking place in the atmosphere itself (Savoie et al. 1992, Ito 1993, Gras 1993, Mulvaney et al. 1993). Chemical weathering is extremely rare in Antarctica, being mainly restricted to the oxidation of surface boulders (Kelly \& Zumberge 1961).

The question of the source of the ions in the active layer above the permafrost table can be approached by comparing the proportions of water-soluble ions with the average composition of the sea water and the mineralogical and chemical compositions of the bedrock typical of each area. It is likely that the $\mathrm{Ni}^{2+}$ and $\mathrm{Al}^{3+}$ concentrations in the Mygehenget samples, which amounted to a few tens of ppm, are not derived from sea water, as the $\mathrm{Cl}$ - and $\mathrm{Na}^{+}$ concentrations, which are typically the highest in sea water, exceed those of $\mathrm{Ni}^{2+}$ and $\mathrm{Al}^{3+}$ by a factor of $10^{6}-10^{7}$ (CRC Handbook of Chemistry and Physics, 1989), whereas in the Mygehenget samples they are only approximately ten times higher than $\mathrm{Ni}^{2+}$ and $\mathrm{Al}^{3+}$ concentrations. It is also impossible to attribute the high $\mathrm{Al}^{3+}$, $\mathrm{Si}^{4+}$ and $\mathrm{Fe}^{2+}$ concentrations in the Basen soil samples to the sea water. In addition, the $\mathrm{Na}^{+} / \mathrm{Cl}-$ , $\mathrm{SO}_{4}{ }^{2-} / \mathrm{Na}^{+}$and $\mathrm{Mg}^{2+} / \mathrm{Na}^{+}$ratios obtained for the sea water differ considerably from those in the nunatak deposits.

By far the highest $\mathrm{SO}_{4}{ }^{2-}$ and $\mathrm{Ca}^{2+}$ concentrations were observed in the samples obtained from the Mygehenget nunatak on Heimefrontfjella, located further inland. The Mygehenget till is highly weathered and contains banded salt accumulations. The salt accumulations and the concentrations of water-soluble ions have been found to increase with the age of the soil in the Dry Valleys of the Transantarctic Mountains (Campbell \& Claridge 1987), so that the fact that the Mygehenget soil contained the highest concentrations of many ions is in line with the more advanced weathering of the surface boulders.

The Utpostane samples have by far the lowest ion concentrations in general. Assuming for the sake of simplification that these levels are determined by just a few factors, the following can be regarded as having contributed to the ion composition: distance from the sea, the accumulation of snow, the time over which the ions may have become enriched in the ground, and possible chemical weathering of the soil parent material. Ion loading from the sea will have been most marked on the coast, where precipitation is higher than in the inland areas, e.g. the accumulation of snow is twice as great in the Vestfjella area as at Heimefrontfjella (Holmlund et al. 1989; Holmlund \& Näslund 1994). The main uncertainty factor is connected with the time over which the ions may have accumulated in the ground.

Two contrasting opinions have been put forward regarding the glacial history of Vestfjella and Heimefrontfjella. The continental ice sheet in the Vestfjella area was once considerably thicker than it is today, so that it is possible that even the summits of Vestfjella were covered during the last advance some $20 \mathrm{ka}$ ago (Lintinen 1996, Lintinen \& Nenonen 1995, 1997). It should be noted that the ice sheet was only slightly thicker in the Heimefrontfjella area at that stage (Lintinen \& Nenonen 1995, 1997). It has also been proposed that Vestfjella may have been ice-free for an extremely long period of time, perhaps from the Pliocene, at which time the subglacial topography indicative of intense erosion is thought to have been formed (Holmlund \& Näslund 1994).

The limited weathering of the till surface boulders, the sparse formation of soils suggest that the lowermost parts of Vestfjella and Heimefrontfjella were exposed to subaerial weathering for a relatively short period of time. In addition, the radiocarbon dates indicate that the snow petrel, Pagodroma nivea, began to nest in the Vestfjella and Heimefrontfjella areas some 8000 years ago (Lintinen \& Nenonen 1995, 1997). The advanced till weathering on the Mygehenget nunatak suggests that the highest nunataks of Heimefrontfjella were ice-free for a considerably longer period of time than those of Vestfjella.

It is justifiable to compare the samples from Basen and Utpostane in tens of water-soluble chemical composition, as both areas may have 
been ice-free only for the past $6000-8000$ years. Also, as both are located at an equal distance from open water, one could assume that the chemical compositions have arisen under conditions that are similar in relative terms, i.e. even the marine aerosol loading must have been of the same order. The most distinct difference between the areas lies in the markedly higher ion concentrations recorded at Basen, whereas both areas had a Na${ }^{+} / \mathrm{Cl}$ - ratio of approximately 1.3. The lower ion concentrations in the Utpostane samples may be attributable to differences in wind conditions in the till areas, and thus in the accumulation of snow. The Basen samples were collected from a vast till plain close to the Aboa research station, which received a continuous snow cover as a result of the storms that occurred there in the $92 / 93$ field season. The till area on the eastern slope of Basen is probably covered by snow for most of the year and thus absorbs the ion load released from it as it melts, while meltwater from the upper parts of the slope will also percolate into the till area along the unfrozen active layer above the permafrost table. The Utpostane till samples, on the other hand, were collected from a large wind scoop eroded by the prevailing winds, so that it is possible that even if there was no appreciable difference in snow accumulation on the even ice sheet, the wind scoop would only contain a fraction of the amount of snow accumulating at Basen. In addition, meltwater will not have entered the till area at Utpostane.

One outstanding difference between the Basen and Utpostane samples lies in the high $\mathrm{Al}^{3+}, \mathrm{Si}^{4+}$ and $\mathrm{Fe}^{2+}$ concentrations in the former. In Basen samples the close correlations observed between the water-soluble ions indicates that they must have originated from the same soluble compounds released by the weathering of fine basaltic material. The clay fraction mineralogy of the Basen till samples involves smectite and mixed-layer clay minerals, which may have contained unstable $\mathrm{Al}^{3+}, \mathrm{Fe}^{2+}$ and $\mathrm{Si}^{4+}$ precipitations. Most of the olivine in the Basen basalts are markedly altered to smectite and chlorite (Luttinen et al. 1994). The high $\mathrm{Fe}^{2+}, \mathrm{Si}^{4+}$ and $\mathrm{Al}^{3+}$ concentrations may also be attributable to the weathering of unstable amorphous material common in vulcanites. The difference in $\mathrm{Fe}^{2+}, \mathrm{Si}^{4+}$ and $\mathrm{Al}^{3+}$ concentrations between the Basen and Utpostane samples may thus result from bedrock dissimilarities, the mineralogical composition of the till and the amount of clay and fines present. In addition, the clay fraction in the Utpostane till samples is approximately $50 \%$ smaller than that in the Basen samples, which will reduce the chemical activity.

\section{CONCLUSIONS}

The soils on the Utpostane and Basen nunataks at Vestfjella and the Mygehenget nunatak at Heimefrontfjella in Western Dronning Maud Land differ markedly in their water-soluble chemical composition. Comparison of the poorly weathered Vestfjella soils with the markedly weathered Heimefrontfjella soils clearly indicates that age increases the $\mathrm{SO}_{4}{ }^{2-}$ and $\mathrm{Mg}^{2+}$ concentrations in particular. The high $\mathrm{Fe}^{2+}, \mathrm{Si}^{4+}$ and $\mathrm{Al}^{3+}$ concentrations of the till deposited on the basaltic bedrock may be attributable to extraction from the active layer, as no corresponding concentrations were observed in the tills in the gabbro area at Utpostane. The Utpostane till, which clay fraction content is low, is considerably less susceptible to extraction than the clay-rich Basen till. $\mathrm{X}$-ray diffraction did not point to any mineralogical changes in the Basen soil, however (Lintinen, 1996). The unstable amorphous material contained in the basalts may have been weatherted, serving together with olivine alteration to give rise to the high $\mathrm{Fe}^{2+}, \mathrm{Si}^{4+}$ and $\mathrm{Al}^{3+}$ concentrations. The higher water-soluble ion concentrations at Basen may also be attributable to other factors, so that some of the local differences observed between the Vestfjella sites located at equal distances from the sea may be assigned to differences in snow accumulation in particular. This is also suggested by the identical $\mathrm{Na}^{+} / \mathrm{Cl}-$ ratios obtained for the Basen and Utpostane samples. 
ACKNOWLEDGEMENTS: We wish to thank the Finnish Antarctic Research Programme (FIN$N A R P)$ and the Geological Survey of Finland (GSF) for financing this work. We are also gra- teful to the staff of the chemical and mineralogical laboratories of the GSF for performing the necessary analyses. 


\section{REFERENCES}

Brook, E.J., Kurz, M,D., Ackert, R.P., Denton, G.H., Brown, E.T., Raisbeck, G.M. \& Yiou, F. 1993. Chronology of Taylor Glacier Advances in Arena Valley, Antarctica, Using in Situ Cosmogenic ${ }^{3} \mathrm{He}$ and ${ }^{10} \mathrm{Be}$. Quaternary Research 39, 11-23.

Campbell, I.B. \& Claridge, G.G.C. 1987. Antarctica: soils, weathering processes and environment. $368 \mathrm{p}$. Elsevier, Amsterdam.

Denton, G.H., Hughes, T.J. and Karlen, W. 1986. Global ice-sheet system interlocked by sea level. Quaternary Research 26, 3-26.

Dort, W. \& Dort, D.S. 1972. Marine Origin of Sodium Sulphate Deposits in Antarctica. In: Adie, R.J. (ed.) Antarctic Geology and Geophysics. Universitetsforlaget, Oslo, 659-671.

Elverhøi, A. 1981. Evidence for a Late Wisconsin glaciation of the Weddell Sea. Nature 293, 641-642.

Furnes, H., Vad, E., Austerheim, H., Mitchell, J. \& Garmann, L. 1987. Geochemistry of basalt lavas from Vestfjella and adjacent areas, Dronning Maud Land, Antarctica. Lithos 20, 337-356.

Gore, D.B., Creagh, D.C., Burgess, J.S., Colhoun, E.A., Spate, A.P. \& Baird, A.S. 1996. Composition, distribution and origin of surficial salts in the Vestfold Hills, East Antarctica. Antarctic Science 8, 73-84.

Gras, J.L. 1993. Condensation nucleus size distribution at Mawson, Antarctica : microphysics and chemistry. Atmospheric Environment 27A, 1427-1434.

Hjelle, A. \& Winsnes, T. 1972. The sedimentary and volcanic sequence of Vestfjella, Dronning Maud Land. In: Adie, R.J. (ed.) Antarctic geology and geophysics, Universitetsforlaget, Oslo, 539-546.

Hollin, T.J. 1962. On the glacial history of Antarctica. Journal of Glaciology 4, 173-195.

Holmlund, P., Isaksson, E., Karlen, W. 1989. Massbalans, isrörelse och isdynamik: preliminära resultatet från fältsesongen 1988/89 i Vestfjella och Heimefrontfjella, Dronning Maud Land, Antarktis. Stocholms Universitetet, Naturgeografiska institutionen, Raport 73, 66 p.

Holmlund, P. \& Näslund, J-O. 1994. The glacially sculptured landscape in Dronning Maud Land, Antarctica, formed by wet-based mountain glaciation and not by the present ice sheet. Boreas 23, 139-148.

Isaksson, E. 1992. Spatial and temporal pattern in snow accumulation and oxygen isotopes, western Dronning Maud Land, Antarctica. Department of Physical Geography, Stockholm University, Report 87, 86 p.

Ito, T. 1993. Size distribution of Antarctic submicron aerosols.Tellus 45B, 145-159.
Jonsson, S. 1988. Observations on physical geography and glacial history of the Vestfjella nunataks in western Dronning Maud Land, Antarctica. Naturgeografiska Institutionen, Stockholms Universitet, Raport 68, 57 p.

Jacobs, J. 1991. Structurelle Entwiclung und Abkühlungsgeschichte der Heimefrontfjella (Westhliches Dronning Maud Land/Antarktika). Berichte zur Polarforschung 97, $141 \mathrm{p}$.

Kelly, W.C. \& Zumberge, J.H. 1961. Weathering of a quarz diorite at Marble Point, McMurdo Sound, Antarctica. Journal of Geology 69, 433-446.

Lintinen, P. 1991. Quaternary Studies on the Northernmost Vestfjella Nunataks, Western Dronning Maud Land, Antarctica. Antarctic Reports of Finland 1. 1619.

Lintinen, P. 1996. Evidence for the former existence of a thicker ice sheet on the Vestfjella nunataks in Western Dronning Maud Land, Antarctica. Bulletin of the Geological Society of Finland 68, 85-98.

Lintinen, P. \& Nenonen, J. 1995. Glacial history of the Vestfjella and Heimefrontfjella nunatak ranges in western Queen Maud Land, Antarctica.VII international symposium on Antarctic earth sciences, Siena 10-15 September 1995. Abstract. p. 245.

Lintinen, P. \& Nenonen, J. 1997. Glacial history of the Vestfjella and Heimefrontfjella nunatak ranges in western Queen Maud Land, Antarctica. Antarctic Geology and Gephysics, in press.

Luttinen, A., Siivola, J. \& Räisänen, M. 1994.The Mafic Igneous Rocks of Vestfjella, Western Queen Maud Land, Antarctica. Antarctic Reports of Finland 4, 12-19.

Marchant, D.R., Denton, G.H., Bockheim, J.G., Wilson, B.S. \& Kerr, A.R. 1994. Quaternary changes in level of the upper Taylor Glacier, Antarctica: implication for paleoclimate and East Antarctic Ice Sheet dynamics. Boreas 23, 29-43.

Mulvaney, R., Coulson, G.J. \& Corr, H.F.J. 1993. The fractionation of sea salts and acids during transport across an Antarctic ice shelf. Tellus 45B, 179-187.

Patzelt, G. 1988. Die geowissenschaftliche expedition in die Kottasberge/Heimefrontfjella und die Kraulberge/Vestfjella-glazialmorphologishe Untersuhungen. In: Fütterer, D.K. (ed.): Beriche zur Polarforschung 58/88, Alfred-Wegener-Institut für Polar- und Meeresforshung, 183-185.

Räisänen, M. 1996. Utpostanen ja Murenin gabrointruusiot Kuningatar Maudin Maalla Antarktiksella. unpublished M.Sc. thesis, University of Helsinki, Department of Geology, 83 p.

Savoie, D.L., Prospero, J.M., Larsen, R.J. \& Salzman, E.S. 1992. Nitrogen and Sulfur Species in Aerosols at Mawson, Antarctica, and Their Relationship to 
Natural Radionuclides. Journal of Atmospheric Chemistry 14, 181-204.

Stuiver, M., Denton, G.H., Hughes, T.J., Fostook, J.L. 1981. History of the marine ice sheet in West Antarctica during the last glaciation: A working hypothesis. In: Denton, G.H. \& Hughes, T.J. (eds.) The last great ice sheets. John Willey and Sons, New York, 319-436 p.
Taalas, P., Huovila, S., Karlsson, K., \& Launiainen, J. 1991. Climatology of the Vestfjella Region. FINNARP-89 symposium, 20-22 March, Espoo, Finland. Antarctic Reports of Finland 1, 133-136. Wilson, M.J. 1987. X-ray powder diffraction methods. In: Wilson, M.J. (ed.) A handbook of determinative methods in clay mineralogy. Glasgow and London: Blacie \& Son Ltd, 27-99. 